\title{
Meningkatkan Hasil Belajar Siswa Kelas XI SMK Melalui Pembelajaran RME Pada Materi Trigonometri
}

\author{
Ni Made Sri Ardana \\ Guru SMKN 1 Labuapi, Indonesia, nm.sriardana@gmail.com
}

\section{INFO ARTIKEL}

Riwayat Artikel:

Diterima: 09-08-2018

Disetujui: 25-10-2018

\section{Kata Kunci:}

Hasil Belajar,

Realistic Mathematics

Education (RME),

Trigonometri

\begin{abstract}
ABSTRAK
Abstrak: Matematika sebagai ilmu dasar memegang peranan yang sangat penting dalam pengembangan sains dan teknologi. Konteks pembelajaran matematika yang jauh dari realita sering membuat siswa tidak dapat menarik korelasinya dengan kehidupan sehari-hari. Salah satu pendekatan pembelajaran matematika yang berorientasi pada matematisasi pengalaman sehari-hari dan menerapkan matematika dalam kehidupan sehari-hari adalah Realistic Mathematics Education (RME). Dengan pembelajaran realistik akan memudahkan siswa belajar secara konkrit terutama pada materi yang dianggap sulit seperti trigonometri khususnya bagi siswa SMKN 1 Labuapi. Adapun nilai hasil tes pada siklus I diperoleh nilai rata-rata sebesar 72 dengan ketuntasan klasikal sebesar 75\%, sedangkan pada siklus II diperoleh nilai ratarata sebesar 75,21 dengan ketuntasan klasikal sebesar 82,51\%, ini menunjukan bahwa pembelajaran yang dilakukan telah mencapai ketuntasan secara klasikal.
\end{abstract}

\begin{abstract}
Mathematics as a basic science plays a very important role in the development of science and technology. The context of mathematics learning that is far from reality often makes students unable to draw correlation with everyday life. One approach to mathematics learning that is oriented to mathematical everyday experiences and applying mathematics in everyday life is Realistic Mathematics Education (RME). With realistic learning, it will be easier for students to learn concretely, especially in material that is considered difficult, such as trigonometry, especially for students of SMK 1 Labuapi. The value of the test results in cycle I obtained an average value of 72 with classical completeness of $75 \%$, while in the second cycle obtained an average value of 75.21 with classical completeness of $82.51 \%$, this indicates that the learning done has been achieving classical completeness.
\end{abstract}

\section{A. LATAR BELAKANG}

Matematika sebagai ilmu dasar memegang peranan yang sangat penting dalam pengembangan sains dan teknologi, karena matematika merupakan sarana berpikir untuk menumbuh kembangkan daya nalar, cara berpikir logis, sistematis dan kritis. Peranan matematika ini tidak hanya terasa dalam bidang matematika tetapi aplikasinya juga pada bidang lain.

Kenyataan menunjukkan bahwa pelajaran matematika diberikan di semua sekolah. Matematika yang diberikan di sekolah disebut matematika sekolah (school mathematics). Menurut Soedjadi (1999:12), matematika sekolah adalah unsur-unsur atau bagian-bagian dari matematika yang dipilih berdasar dan diorientasikan kepada: (1) Makna kependidikan, yaitu untuk mengembangkan kemampuan dan kepribadian peserta didik, dan (2) Tuntutan perkembangan yang nyata dari lingkungan hidup yang senantiasa berkembang seiring dengan kemajuan ilmu dan teknologi.

Konteks pembelajaran matematika yang jauh dari realita sering membuat siswa tidak dapat menarik korelasinya dengan kehidupan sehari-hari terlalu abstrak membuat siswa sulit membuat visualisasinya. Integrasi matematika dengan ilmu lain yang lebih realistik menurut pandangan siswa sangatlah di perlukan untuk membangun " image" bahwa matematika itu dibutuhkan, matematika itu mengasyikkan, terkait dengan agama, sosial, budaya dan termasuk materi keislaman yang secara realistik sangatlah di butuhkan dalam kehidupan beragama.

Pendekatan dan strategi pembelajaran matematika hendaklah diawali dari konkrit ke abstrak, dari sederhana ke kompleks dan dari mudah ke sulit, dengan menggunakan berbagai sumber belajar. Hendaknya para siswa aktif dengan berbagai cara untuk mengkontruksi atau membangun sendiri pengetahuannya. Suatu rumus, konsep atau prinsip 
dalam matematika, seyogyanya ditemukan sendiri oleh siswa di bawah bimbingan guru (guided reinvention), sehingga membuat mereka terbiasa melakukan penyelidikan dan menemukan sesuatu (Depdiknas, 2003: 4).

Salah satu pendekatan pembelajaran matematika yang berorientasi pada matematisasi pengalaman sehari-hari dan menerapkan matematika dalam kehidupan sehari-hari adalah Realistic Mathematics Education (RME). Pendekatan ini pertama kali dikembangkan di Belanda sekitar 30 tahun yang lalu. Pendekatan ini didasarkan pada konsep Freudenthal yang mengatakan bahwa matematika merupakan aktivitas manusia (human activities). Ide utama RME selanjutnya pada penelitian ini RME diistilahkan dengan Pembelajara Matematika Reaistik adalah siswa harus diberi kesempatan untuk menemukan kembali ide dan konsep matematika dengan atau tanpa bimbingan orang dewasa (Gravemeijer 1994:4). Upaya ini dilakukan melalui penjelajahan berbagai situasi dan persoalan-persoalan "realistik", yakni yang berkaitan dengan realitas atau situasi yang dapat dibayangkan siswa.

Pembelajaran matematika realistik menggunakan masalah-masalah kontekstual (contextual problems) sebagai titik awal dalam belajar matematika. Siswa diminta mengorganisasikan dan mengidentifikasikan aspekaspek matematika yang terdapat pada masalah tersebut. Kepada para siswa juga diberikan kebebasan penuh untuk mendeskripsikan, menyederhanakan, menginterpretasikan dan menyelesaikan masalah kontekstual tersebut menurut cara mereka sendiri baik secara individu maupun kelompok, berdasarkan pengalaman atau pengetahuan awal yang telah mereka miliki. Kemudian dengan atau tanpa bantuan guru, para siswa diharapkan dapat menggunakan masalah kontekstual tersebut sebagai sumber munculnya konsep atau pengertian-pengertian matematika yang meningkat abstrak (Soedjadi, 2001a: 3).

Dengan pembelajaran matematika realistik, diharapkan aktivitas pembelajaran tidak lagi terpusat pada guru tetapi terpusat pada siswa, bahkan terpusat pada pemecahan masalah kontekstual. Guru berfungsi sebagai pembimbing dalam menyeleksi dan mengarahkan berbagai konstribusi siswa melalui pemecahan masalah kontekstual yang diberikan di awal pembelajaan.

Melalui pembelajaran matematika realistik, akan lebih mengakrabkan matematika dengan lingkungan siswa, melalui pengaitan konsep-konsep/prinsipprinsip matematika dengan pengalaman siswa sehari-hari, dapat menyebabkan siswa tidak mudah lupa terhadap konsep-konsep/prinsip-prinsip matematika yang ia pelajari. Bahkan ia juga akan lebih mudah mengaplikasikan konsep atau prinsip matematika tersebut, untuk menyelesaikan soal maupun untuk menyelesaikan permasalahan hidup sehari-hari. Sebagaimana Panhuizen (dalam Fauzi, 2002: 2), menyatakan bahwa bila siswa belajar matematika terpisah dari pengalaman mereka sehari-hari, maka siswa akan cepat lupa dan tidak akan dapat mengaplikasikan matematika.

Trgonomtri merupakan salah satu mata pelajaran matematika yang memiliki peran penting dalam kehidupan sehari-hari. Namun kenyataan yang terjadi walaupun pokok bahasan tersebut sudah akrab dalam kehidupan siswa tetapi masih banyak siswa yang kurang memahami pokok bahasan tersebut. Pokok bahasan Trigonomtri sosial dipilih karena dua alasan. Pertama berdasarkan hasil wawancara peneliti dengan beberapa siswa SMKN 1 Labuapi diperoleh informasi bahwa pokok bahasan trigonometri masih merupakan pokok bahasan yang agak sulit bagi siswa. Kedua pokok bahasan ini sering dijumpai siswa dalam kehidupan sehari-hari.

Berdasarkan uraian di atas, maka peneliti tertarik untuk membahas tentang penerapan pembelajaran matematika realistik pada materi pokok trigonometri di kelas XI SMKN 1 Labuapi.

\section{B. METODE PENELITIAN}

Penelitian ini termasuk penelitian tindakan kelas (Action Research). Penelitian Tindakan kelas (PTK) adalah suatu penelitian yang dilakukan oleh guru atau guru di dalam kelas dengan tujuan untuk memperbaiki kinerja sebagai guru atau guru, sehingga hasil belajar siswa menjadi meningkat (Wardani, 2003:36).

Desain yang digunakan dalam penelitian ini mengacu pada model Kemmis dan Taggart (dalam Depdikbud, 1999) yang berlangsung dalam dua siklus. Alur kegiatan setiap siklus terdiri dari 4 (empat) komponen, yaitu: rencana tindakan (plan), pelaksanaan tindakan (action), observasi atau evaluasi (observation/evaluation), dan refleksi (reflection).

Sumber data dalam penelitian ini adalah satu kelas dari kelas XI SMK Negeri I Labuapi yang mngikuti pembelajaran. Untuk mengetahui apakah penerapan pembelajaran ini dapat diterapkan kepada siswa yang mempunyai kemampuan berbeda-beda, maka terlebih dahulu siswa dikelompokkan yang terdiri dari 4 atau 5 orang siswa. Proses penentuan kelompok diawali dengan membagi dalam tiga kelompok kemampuan, yaitu kelompok kemampuan rendah, kelompok kemampuan sedang, dan kelompok berkemampuan tinggi berdasarkan hasil tes awal. Selanjutnya subjek wawancara dalam penelitian ini dipilih 4 orang dengan kualifikasi I orang siswa berkemampuan tinggi, 2 orang siswa berkemampuan sedang, dan 1 orang siswa berkemampuan rendah. Jadi subjek wawancara 
dalam penelitian ini adalah 4 orang siswa dengan latarbelakang kemampuan yang berbeda dengan pertimbangan agar penjaringan data lebih fokus dan memperoleh data dari semua aspek kemampuan. Derajat kemampuan akademik siswa ditentukan dari hasil tes awal bersama-sama dengan guru kelas I. Keterlibatan guru kelas I dimaksudkan bahwa yang mengetahui perbedaan kemampuan matematika dengan baik dan latar belakang siswa adalah guru kelas I itu sendiri. Selain itu, keterlibatan guru kelas I dimaksudkan agar dapat membantu menentukan subjek wawancara yang diajak berkomunikasi untuk memudahkan wawancara.

Prosedur pengumpulan data penelitian, dilakukan sebagai berikut:

1. Tes hasil belajar; untuk mengukur kemampuan kognitif siswa selama proses pembelajaran berlangsung.

2. Wawancara dolakukan untuk memperoleh secara mendalam tentang tingkat pemahaman dan respos siswa pada materi trigonometri.

3. Observasi; untuk mengamati: (a) keaktifan siswa dalam proses pembelajaran, (b) proses penerapan strategi pembelajaran, keterampilan pemecahan berdasarkan masalah.

4. Angket; untuk mengukur: (a) sikap terkait materi pelajaran, dan (b) respons terhadap penerapan strategi pembelajaran.

Catatan lapangan; untuk mencatat aktivitas pelaksanaan tindakan yang tidak terekam dalam instrumen penelitian. Instrumen penelitian yang digunakan dalam penelitian ini, diuraikan lebih lanjut.

\section{HASIL DAN PEMBAHASAN}

Untuk hasil pelaksanaan pembelajaran realistik pada materi trigonometri diperoleh hasil berikut: Hasil seluruh tindakan pada siklus I dapat dilihat selengkapnya pada tabel berikut:

TABEL 1

HASIL OBSERVASI SIKLUS I

\begin{tabular}{lll} 
Parameter & Persentase & Kategori \\
Aktivitas Guru & $83,33 \%$ & Baik \\
\hline Aktivitas siswa & $84,71 \%$ & Baik \\
\hline
\end{tabular}

TABEL 2

HASIL OBSERVASI SIKLUS II

\begin{tabular}{lcl}
\hline Keterangan & $\begin{array}{c}\text { Persentase } \\
\text { rata-rata }\end{array}$ & $\begin{array}{l}\text { Kriteria taraf } \\
\text { keberhasilan }\end{array}$ \\
\hline Aktivitas Guru & $93,33 \%$ & Sangat Baik \\
Aktivitas siswa & $86,71 \%$ & Baik \\
\hline
\end{tabular}

Adapun nilai hasil tes pada siklus I diperoleh nilai rata-rata sebesar 72 dengan ketuntasan klasikal sebesar 75\%, dimana ini menunjukan bahwa pembelajaran perlu dilanjutkan ke siklus II. Pada siklus II diperoleh nilai rata-rata sebesar 75,21 dengan ketuntasan klasikal sebesar 82,51\%, dimana ini menunjukan bahwa pembelajaran yang dilakukan telah mencapai ketuntasan secara klasikal.

Sebagaimana telah disepakati bahwa dalam penelitian ini guru bertindak sebagai pelaksana tindakan dan satu teman sejawat bertindak sebagai observer pelaksanaan pembelajaran di kelas. Dalam penelitian ini, sebelum dan selama penelitian peneliti selalu berkoordinasi dengan observer mengenai pelaksanaan pembelajaran realistik materi trigonometri yang dilakukan di kelas. Pada setiap awal tindakan, guru menyampaikan materi dan tujuan pembelajaran. Penyampaian tujuan pembelajaran yang hendak dicapai bertujuan agar siswa dapat mengetahui arah kegiatan belajar mereka dan apa yang dipelajari sehingga siswa dapat terarah pada tujuan yang hendak dicapai, termotivasi dan terpusat dalam belajar. Kemudian guru berupaya menimbulkan minat dan rasa ingin tahu siswa tentang materi yang akan dipelajari. Selanjutnya guru mengajukan pertanyaan yang berhubungan dengan materi trigonometri dan siswa menanggapi. Dalam pengajuan pertanyaan guru harus menyesuaikan dengan pemahaman awal yang ada di benak siswa sehingga memungkinkan mereka menggunakan pengalaman sebelumnya atau pengetahuan yang ada secara langsung, setelah itu membangkitkan pengetahuan prasyarat siswa dengan mengajukan beberapa pertanyaan tentang materi sebelumnya yang bertujuan untuk mengetahui kemampuan awal siswa. Pengetahuan awal sangat diperlukan bagi siswa sehingga siswa tidak kesulitan dalam belajar selanjutnya. Bendal dan Galili (dalam Istyanti, 2005:99) menyatakan bahwa jika guru tidak memperhatikan pengetahuan awal siswa maka siswa akan mengalami kesulitan belajar pada tahap berikutnya. Selain itu, ketrampilan dalam membuka pelajaran yang dapat menciptakan suasana pembelajaran yang baik juga perlu diperhatikan sehingga siswa siap secara mental dan memperhatikan apa yang dipelajari.

Dari kegiatan pembelajaran yang dilakukan pembelajaran yang dilakukan pada siklus I belum mencapai ketuntasan secara klasikal. Hal ini disebabkan aktivitas siswa yang masih rendah. Oleh karenanya pembelajaran dilanjutkan pada siklus II.

\section{SIMPULAN DAN SARAN}

Berdasarkan hasil dan pembahasan dapat disimpulkan bahwa penerapan pembelajaran realistik dapat meningkatkan pemahaman siswa kelas XI Pada materi trigonometri. Saran yang dapat disampaikan berdasarkan hasil penelitian ini yakni (1) Bagi pengajar, dalam mengajarkan siswa dengan model pembelajaran realistik; (2) Dalam proses pembelajaran, hendaknya siswa diberikan lebih banyak kesempatan untuk bekerja, bila perlu memberikan kesempatan kepada siswa untuk saling 
berdiskusi dengan temannya. Pengajar juga harus pandai mengajukan pertanyaan-pertanyaan yang sifatnya mengarahkan tanpa harus memberikan jawaban langsung kepada siswa; dan (3) Bagi peneliti yang ingin meneliti kajian yang sama, hendaknya dapat melakukan penelitian lebih lanjut dengan memperhatikan kelemahan-kelemahan penelitian ini, sehingga peningkatan kualitas belajar matematika dapat terlaksana secara berkesinambungan.

\section{UCAPAN TERIMAKASIH}

Ucapan terimakasih penulis sampaikan kepada semua pihak yang telah membantu dan memberikan dukungan terutama kepada Bapak Kepala Sekolah dan rekan-rekan guru SMKN 1 Labuapi, sehingga penelitian ini dapat diselesaikan sesuai waktu yang telah direncanakan.

\section{REFERENSI}

[1] Alhaddad, S.F. (2002). "Pembelajaran Matematika Realistik Pokok Bahasan Pecahan di SD Muhammadiyah 4 Surabaya" Tesis Magister Pendidikan. Universitas Negeri Surabaya.

[2] Arends, Richard I. (1997). Classroom Instruction and Management. New York: McGraw-Hill.

[3] Arikunto, Suharsimi. (2010). Prosedur Penelitian Suatu Pendekatan Praktek. Jakarta: Rineka Cipta

[4] Harjanto. (2002). Perencanaan Pengajaran. Jakarta: Rineka Cipta.

[5] Marpaung, Y. (2002). Pendidikan Matematika Realistik Indonesia: Perubahan Paradigma dalam Pembelajaran Matematika di Sekolah. Jurnal Matematika atau Pembelajarannya Edisi Khusus

[6] Mukhlis. (2005). "Pembelajaran Matematika Realistik Materi Pokok Aritmetika Sosial di Kelas VII SMP Negeri 1 Pallangga". Tesis Magister Pendidikan. Universitas Negeri Surabaya.

[7] Krulik dan Reys. (1980). Problem solving in School Mathematics. Washington D.C :NCTM.

[8] Purwanto. (2013). Evaluasi Hasil Belajar. Yogyakarta: Pustaka Pelajar

[9] Slavin, Robert E. (1994). Educational Psychology: Theories and Practice. Fourth Edition. Masschusetts. Allyn and Bacon Publishers.

[10] Sugiyono. (2013). Metodologi Penelitian Pendidikan (Pendekatan Kuantitatif, Kualitatif dan $R \& D)$, Cet .X. Bandung: Alfabeta. 